\title{
Addition of inorganic or organic phosphorus enhances nitrogen and carbon fixation in the oligotrophic North Pacific
}

\author{
Katie S. Watkins-Brandt ${ }^{1}$, Ricardo M. Letelier ${ }^{1}$, Yvette H. Spitz ${ }^{1}$, \\ Matthew J. Church ${ }^{2}$, Daniela Böttjer ${ }^{2}$, Angelicque E. White ${ }^{1, *}$ \\ ${ }^{1}$ College of Oceanic and Atmospheric Sciences, Oregon State University, Corvallis, Oregon, USA \\ ${ }^{2}$ Department of Oceanography, School of Ocean and Earth Science and Technology, University of Hawai'i at Mãnoa, \\ Honolulu, Hawaii, USA
}

\begin{abstract}
We present a spatially extensive record of dinitrogen $\left(\mathrm{N}_{2}\right)$ fixation rates and distributions of $\mathrm{N}_{2}$ fixing microorganisms along with the results of exogenous phosphorus (P) addition experiments conducted during a series of cruises in the North Pacific Subtropical Gyre (NPSG). We measured the $\mathrm{N}_{2}$ and carbon (C) fixation rates of natural plankton assemblages in response to the addition of methylphosphonate (MPn), a dissolved organic phosphorus (DOP) compound, and dissolved inorganic phosphorus (DIP). Results are compared to parallel unamended controls. These experiments produced 3 major findings: (1) MPn and DIP were utilized with equal metabolic efficiency over a single photoperiod, (2) the bulk of the enhanced $\mathrm{N}_{2}$ fixation rates were within the range of those previously reported in the NPSG, suggesting that P levels in this region can be saturating but were not at the time of sampling and (3) MPn and DIP additions stimulated C fixation rates beyond estimated contributions by diazotrophs, and hence both DIP and bioavailable DOP additions could lead to enhancement of net primary productivity on short time-scales. Our results suggest that the rate of $\mathrm{N}_{2}$ fixation in our study region may have been restricted by the availability and/or the composition of the total P pool (inorganic and organic P) during our field season.
\end{abstract}

KEY WORDS: Phosphorus · Nitrogen fixation · Dissolved organic matter

\section{INTRODUCTION}

The surface mixed layer of subtropical oceanic gyres is often characterized by a deficit of dissolved inorganic nitrogen (DIN) relative to dissolved inorganic phosphorus (DIP), where DIN concentrations are nearly always at or below the detection limit of standard autoanalyzer technology $\left(\sim 30 \mathrm{nmol} \mathrm{l}^{-1}\right)$. For this reason the rate of primary productivity in the oligotrophic subtropical gyres of the Pacific and Atlantic basins has long been held to be restricted by the supply of reduced nitrogen (N) (Perry \& Eppley 1981, Wu et al. 2000, Karl 2002, Moore et al. 2008). Under such conditions, biological dinitrogen $\left(\mathrm{N}_{2}\right)$ fixation, the process by which select genera of marine microorganisms convert $\mathrm{N}_{2}$ into cellular $\mathrm{N}$, can act as a source of new $\mathrm{N}$ and support a significant fraction of net primary productivity (Capone 2001, Karl et al. 2002, Mahaffey et al. 2005). Despite the documented and substantial contributions of $\mathrm{N}_{2}$ fixation to productivity, elemental cycling and particle export in oligotrophic regions, the nutritional and ecological controls of marine diazotrophs have not been firmly established (Vitousek \& Howarth 1991, Zehr \& Ward 2002).

While $\mathrm{N}_{2}$ fixation may lead to short-lived mitigation of community scale nitrogen $(\mathrm{N})$ limitation, the growth of diazotrophs themselves is ultimately limited by other elements such as phosphorus $(\mathrm{P})$, iron $(\mathrm{Fe})$ and inorganic carbon (Karl et al. 1997, Sañudo-Wilhelmy et al. 2001, Hutchins et al. 2007). In the North Pacific sub- 
tropical gyre (NPSG), Karl et al. (2001b) have hypothesized that climate-driven shifts in the ecology of the NPSG early in the 20th century led to enhanced $\mathrm{N}_{2}$ fixation and a concomitant drawdown of P. The authors further suggested that this 'domain shift' would result in a progressive shift from $\mathrm{N}$ limitation to $\mathrm{P}$ limitation of primary productivity (Karl et al. 2001b) and eventually to $\mathrm{P}$ limitation of diazotrophs. To address the potential P limitation of any functional group in pelagic ecosystems, one must also consider that while inorganic $\mathrm{P}$ (phosphate) is often preferred for growth, P bound in certain organic complexes is bioavailable (Cembella et al. 1982, Dyhrman et al. 2007) and can be present in greater concentrations than inorganic pools. In the NPSG, DIP (dissolved inorganic P) concentrations in surface waters are low $\left(<100 \mathrm{nmol} \mathrm{l}^{-1}\right)$ relative to biological demands (Karl et al. 2001a, Karl \& Björkman 2002) and relative to dissolved organic $P$ (DOP) pools which range from 200 to $300 \mathrm{nmol} \mathrm{l}^{-1}$. DOP clearly represents a large potentially bioavailable P pool (Björkman et al. 2000). Partial characterization of the high molecular weight fraction of marine DOP by nuclear magnetic resonance (NMR) spectroscopy reveals a resource comprised of esters and phosphonates in a ratio of $3: 1$, respectively (Kolowith et al. 2001). While both of these compound classes are bioavailable to microbes, including diazotrophs, there remains considerable uncertainty regarding the extent to which bioavailable P (inorganic + labile organic) regulates diazotrophy, net productivity, and plankton community structure in the oligotrophic ocean.

In the NPSG, Björkman et al. (2000) have shown that the addition of certain DOP compounds to seawater samples resulted in hydrolysis rates 50 times or more in excess of ambient $\mathrm{P}$ uptake rates. Later, using an isotope dilution technique, Björkman and Karl (2003) demonstrated that the microbial community at Station ALOHA $\left(22.45^{\circ} \mathrm{N}, 158^{\circ} \mathrm{W}\right.$; the sampling station for the Hawaii Ocean Time-series program) simultaneously utilized DOP and DIP for P nutrition, with rates of DOP uptake equivalent to those of DIP uptake. This and other work (Karl et al. 2008, Duhamel et al. 2010) elucidated the importance of DOP as a source of P supporting plankton nutrition in the NPSG. However, studies are lacking of how natural assemblages of diazotrophs respond to additions of DOP relative to DIP.

In the present study, we conducted a series of experiments aimed at (1) characterizing the spatial variability of $\mathrm{N}_{2}$ fixation and diazotroph community structure in the NPSG and (2) assessing the short-term (24 h) $\mathrm{N}_{2}$ fixation and carbon (C) productivity responses of natural plankton populations to saturating additions of DIP and a model DOP compound, methylphosphonate (MPn). MPn was selected as a target compound based on previous laboratory and in situ studies confirming active MPn hydrolysis by the diazotroph Trichodesmium (Dyhrman et al. 2006, Karl et al. 2008, White et al. 2010). The overarching objectives of this work were to measure the response of microbial communities to the addition of a potentially limiting nutrient $(\mathrm{P})$ as a direct test of contemporaneous resource limitation and to compare the community level metabolic response to the addition of MPn relative to DIP.

\section{MATERIALS AND METHODS}

In July through August of 2008, a series of experiments were conducted (1) near the frontal boundary separating the North Pacific subtropical and subarctic gyres (Pacific Open Ocean Bloom cruise: $\mathrm{POOB}, 28^{\circ} \mathrm{N}$ to $32^{\circ} \mathrm{N}, 2-16 \mathrm{July}$ ) and (2) near the Hawaiian Islands (Ocean PERturbation EXperiment cruise: OPEREX, $22^{\circ} \mathrm{N}$ to $26^{\circ} \mathrm{N}, 30$ July-14 August). The regional mean satellite-derived sea surface temperature (SST) and chlorophyll a (chl a) fields for these cruise periods were obtained from $4 \mathrm{~km}$, level-3 MODIS (MODerate resolution Imaging Spectroradiometer) data provided by NASA/Goddard Space Flight Center (accessed at http://oceancolor.gsfc.nasa.gov). Each cruise track is shown relative to the mean July to August SST and chl a fields averaged over the specific cruise duration (Fig. 1). The sea surface height anomaly field relative to the POOB and OPEREX cruise efforts (Fig. 2) was obtained from the $1 / 3^{\circ}$ by $1 / 3^{\circ}$ resolution, merged satellite altimetry data for July to August 2008. These altimeter products were produced by Ssalto/Duacs and distributed by Aviso, with support from Cnes.

Experimental design. Experimental manipulations were designed to examine the change in $\mathrm{C}$ and $\mathrm{N}_{2}$ fixation rates over a $24 \mathrm{~h}$ period in response to additions of either $\mathrm{KH}_{2} \mathrm{PO}_{4}$ (Fisher Scientific 7778, $\geq 99 \%$, denoted below as DIP) or MPn (Sigma-Aldrich 64259, $\geq 98 \%$ ). The rates of $\mathrm{N}_{2}$ and $\mathrm{C}$ fixation in these treatments were compared to rates measured in parallel incubations with no added P. At all stations, water was collected using a Sea-Bird CTD rosette equipped with 24 polyvinyl chloride 121 sampling bottles; the rosette/ bottles were not treated for trace metal free conditions. All samples came from the upper $50 \mathrm{~m}$ of the water column where irradiance varied between approximately 10 and $60 \%$ of the surface flux. Acid-washed polycarbonate incubation bottles (4.4 l) were filled to overflowing with whole seawater (no pre-screening). Care was taken to ensure that no bubbles were present before sealing each bottle with a septum cap. Incubation bottles were transferred to one of 2 on-deck incubators plumbed with surface seawater and shaded to approximate the light levels from which the samples originated: either (1) $\sim 30 \%$ of the surface irradiance or 


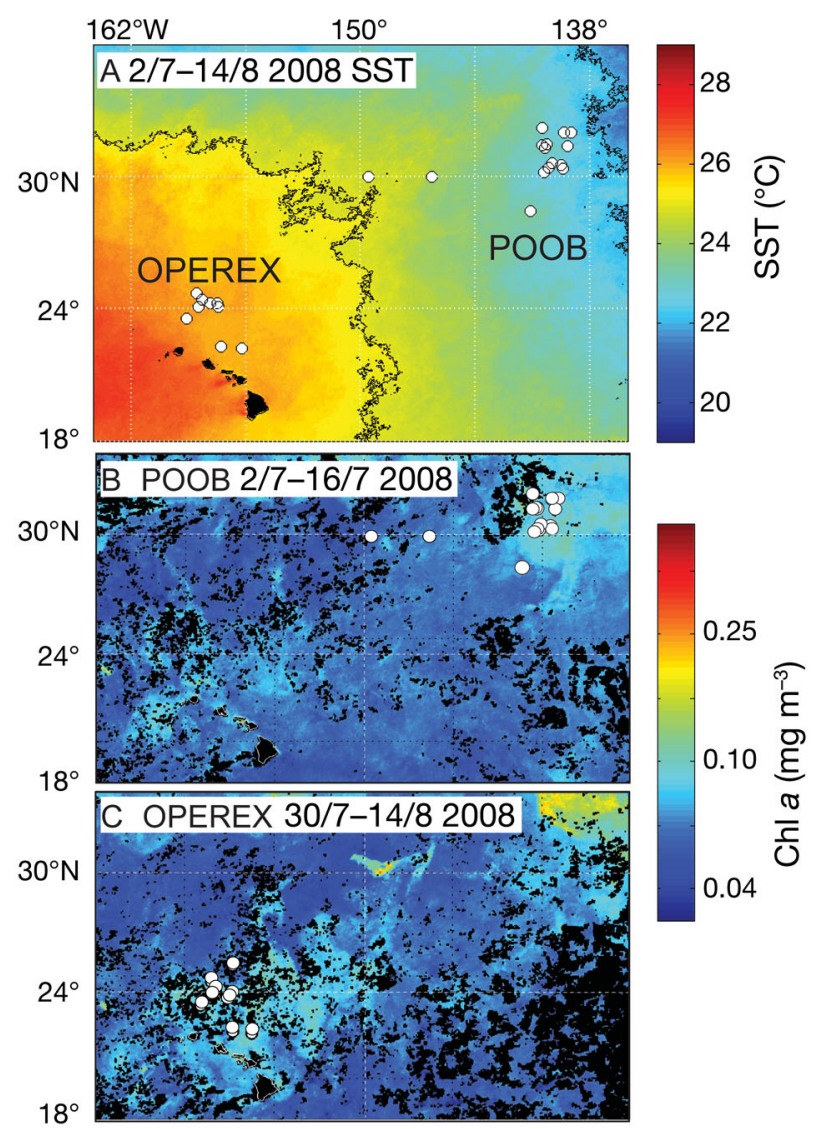

Fig. 1. (A) Mean (July-August 2008) MODIS SST $\left({ }^{\circ} \mathrm{C}\right)$. Solid black contour $=25^{\circ} \mathrm{C}$ isotherm. (B) MODIS chl a $\left(\mathrm{mg} \mathrm{m}^{-3}\right)$ averaged over the duration of POOB (2-16 July) and (C) OPEREX (30 July-14 August). O = station locations

(2) $\sim 60 \%$ of the surface irradiance. Whenever possible, controls (no P additions) as well as experimental treatments (MPn and/or DIP additions) were incubated in duplicate. All incubations began at near dawn and lasted $24 \mathrm{~h}$.

Nitrogen and carbon fixation rate determinations. All $\mathrm{N}_{2}$ fixation rate measurements employed the ${ }^{15} \mathrm{~N}_{2}$ isotopic tracer method described by Montoya et al. (1996) in parallel with ${ }^{13} \mathrm{C}$-productivity measurements with rate calculations as per Legendre \& Gosselin (1997). Using a gas tight syringe, $2.0 \mathrm{ml}$ of ${ }^{15} \mathrm{~N}_{2}$ gas (99 atom\%, Cambridge Scientific) was injected into each bottle and the bottles were inverted several times. Immediately following ${ }^{15} \mathrm{~N}_{2}$ additions, $0.5 \mathrm{ml}$ of $47 \mathrm{mM}$ bicarbonate $\left(\mathrm{NaH}^{13} \mathrm{CO}_{3}\right)$ stock was injected into each bottle with a plunger-type syringe and the bottles were again gently mixed by inversion. For experimental treatments only, following the injection of both ${ }^{15} \mathrm{~N}_{2}$ and $\mathrm{NaH}^{13} \mathrm{CO}_{3}$, each $4.4 \mathrm{l}$ polycarbonate bottle was spiked using a Luer-lock syringe with either DIP or MPn to reach a final concentration of $5 \mu \mathrm{M}$

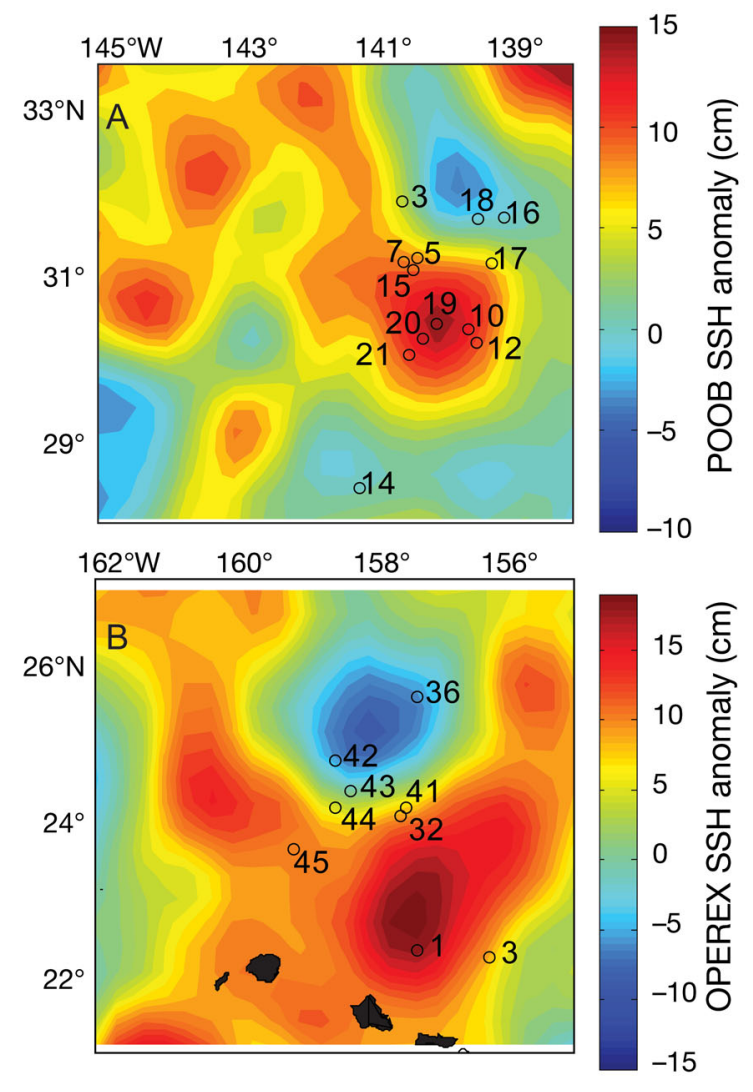

Fig. 2. Weekly sea surface height (SSH) anomaly field derived from Aviso data for the week of (A) 9 July 2008 (POOB cruise) and (B) 6 August 2008 (OPEREX cruise). All stations for which $\mathrm{N}$ fixation data were collected are shown with the exception of Stns 1-2 for POOB which were located at $30^{\circ} \mathrm{N}$, $145-150^{\circ} \mathrm{W}$. Sampling efforts for OPEREX were focused at sites where surface slicks of Trichodesmium were observed along a transition between a cyclonic and anticyclonic eddy

(Stns 41-45)

above ambient $\mathrm{P}$ levels. Reported half-saturation coefficients $\left(\mathrm{K}_{\mathrm{s}}\right)$ for specific-uptake of DIP in natural populations of Trichodesmium range from 0.4 to $9.0 \mu \mathrm{mol} \mathrm{l}^{-1}$ (McCarthy \& Carpenter 1979, Sohm \& Capone 2006). Values of $\mathrm{K}_{\mathrm{s}}$ for labile DOP uptake are presently unknown for in situ populations of oceanic diazotrophs, as are DIP uptake kinetics for uncultured diazotrophic taxa (including the uncultivated Group A, termed UCYN-A, Crocosphaera, and Richelia/diatom symbioses). Given the low affinity for DIP reported for Trichodesmium and the uncertainty of MPn uptake kinetics, we selected a level of P addition $(5 \mu \mathrm{M})$ intended to ensure that the full microbial assemblage was exposed to saturating, but not inhibitory, concentrations of DIP or DOP. Controls were treated and incubated under identical conditions but without an external addition of $\mathrm{P}$ to approximate the ambient rate of $\mathrm{C}$ and $\mathrm{N}_{2}$ fixation in surface waters. 
Incubations were terminated by filtering the entire incubation volume onto a $25 \mathrm{~mm}$ pre-combusted glass fiber filter (GF/F, Whatman); following filtration, the filters were stored at $-20^{\circ} \mathrm{C}$ until later analysis. Once ashore, samples were acid-fumed, dried overnight at $60^{\circ} \mathrm{C}$ and then encapsulated in tin and silver capsules. Particulate $\mathrm{C}, \mathrm{N}$ and the isotopic composition of particulate material $\left(\delta^{15} \mathrm{~N}_{\mathrm{PN}}\right.$ and $\left.\delta^{13} \mathrm{C}_{\mathrm{PC}}\right)$ were determined using a PDZ Europa ANCA-GSL elemental analyzer interfaced to a PDZ Europa 20-20 isotope ratio mass spectrometer in the University of California Davis stable isotope facility.

To contextualize the productivity observed in our study, we also present rates of $\mathrm{C}$ and $\mathrm{N}_{2}$ fixation from unamended seawater samples measured by other research groups at or around Station ALOHA during the 2004-2007 field seasons (Fong et al. 2008, Grabowski et al. 2008, Church et al. 2009). These rate measurements were conducted using methodologies similar to those outlined above although a subset of samples were incubated using in situ arrays rather than on deck incubators (see Church et al. 2009).

Lastly, during the OPEREX cruise, as we crossed through mesoscale features that coincided with visible surface slicks of Trichodesmium, we collected duplicate samples from $25 \mathrm{~m}$ and $45 \mathrm{~m}$ for subsequent sizefractionated $\mathrm{C}$ and $\mathrm{N}_{2}$ fixation rate determinations. For these measurements, 2 treatments were prepared: (1) whole water incubations filtered onto a combusted GFF filter (total) and (2) incubations pre-filtered through a $10 \mu \mathrm{m}$ polycarbonate with the filtrate subsequently retained onto a GFF filter $(<10 \mu \mathrm{m})$. $\mathrm{N}_{2}$ fixation rates in the large $(>10 \mu \mathrm{m})$ size fraction were calculated as the difference between rate measurements in these 2 samples $(>10 \mu \mathrm{m}=$ Total $-<10 \mu \mathrm{m})$. Determination of size-fractionated rates was intended to provide insight into the distribution of $\mathrm{N}_{2}$ fixation between small unicellular diazotrophs and large filamentous diazotrophs along this section of our study region.

Diazotroph distributions and nifH gene quantification during РООВ 2008. Distributions of several groups of diazotrophic cyanobacteria common to the upper ocean waters of the NPSG were identified based on quantitative polymerase chain (QPCR) amplification of nitrogenase reductase (nifH) genes. Seawater samples for nifH gene QPCR amplification were collected from the POOB 2008 cruise at 4 depths representing the $\sim 60, \sim 20, \sim 10$, and $\sim 1 \%$ light levels (depths varied from 9-20, 33-47, 46-65, and 102-143 m, respectively). Water was subsampled from the CTD rosette bottles into acid-washed 101 polyethylene carboys and filtered onto $0.22 \mu \mathrm{m}$ pore size Sterivex-GS (Millipore) filter capsules. Filters were capped, flash frozen in liquid nitrogen and stored frozen at $-80^{\circ} \mathrm{C}$ until extraction.
In the shore-based laboratory, $1 \mathrm{ml}$ of a cell lysis buffer (20 mM Tris-HCL, pH 8.0; 2 mM EDTA, pH 8.0; $1.2 \%$ Triton $\mathrm{X}$ and $20 \mathrm{mg} \mathrm{ml}^{-1}$ lysozyme) was injected into each filter capsule using a $5 \mathrm{ml}$ syringe. Filters (with syringes still attached) were placed into a hybridization oven at $37^{\circ} \mathrm{C}$ and then vortexed for $\sim 15$ min intervals over $1.5 \mathrm{~h}$. Filters were removed from the oven, and the buffer was removed from the filter capsule by syringe and dispensed into $2 \mathrm{ml}$ microcentrifuge tubes; $42 \mu \mathrm{l}$ of proteinase $\mathrm{K}$ and $334 \mu \mathrm{l}$ buffer AL (Qiagen) was added to each sample and samples were vortexed and placed in a hybridization oven at $70^{\circ} \mathrm{C}$ for $30 \mathrm{~min}$. Following this incubation, $700 \mu \mathrm{l}$ of $100 \%$ ethanol was added to each sample, the microcentrifuge tubes were vortexed and samples were transferred to DNeasy spin columns (Qiagen) where DNA was purified following the manufacturer's recommended protocols.

Abundances of nifH genes were determined using the QPCR assay described in Church et al. (2005). For this study, we examined the spatial variability of 6 phylotypes frequently retrieved from PCR amplified nifH gene clone libraries at Station ALOHA (Dominic et al. 1998, Zehr et al. 2001, Church et al. 2008). QPCR primer and probe sets targeting the following nifH phylotypes were used: Trichodesmium spp.; 3 groups of heterocystous cyanobacteria (termed Het1, Het2, and Het3, respectively); and 2 groups of nifH containing unicellular cyanobacteria including UCYN-A and phylotypes whose nifH sequences are 97-99\% identical to Crocosphaera watsonii. Descriptions of the primers and probes used for these reactions can be found in Church et al. $(2005,2008)$. All QPCR reactions were run in duplicate; the detection limit for these reactions corresponded to $\sim 30$ gene copies $1^{-1}$.

Ancillary measurements. Whole seawater samples were collected for nutrient analyses from each depth sampled (all within the upper $50 \mathrm{~m}$ ) in acid-washed polycarbonate bottles and stored at $-20^{\circ} \mathrm{C}$ until later analyses. In the laboratory, after thawing, subsamples of these collections were transferred to acid-cleaned Teflon digestion bombs and oxidized via the alkaline persulfate digestion described by Valderrama (1981). After oxidation, total dissolved P (TDP) was measured as described by Strickland \& Parsons (1972). Low level soluble reactive $\mathrm{P}$ (assumed to be equivalent to DIP) was measured via the MAGIC (MAGnesiumInduced Coprecipitation) method of Karl \& Tien (1992). Dissolved organic phosphorus (DOP) concentrations were calculated as the difference between TDP and DIP concentrations. Chl a concentrations were determined fluorometrically using a Turner Model 10-AU fluorometer. Samples were extracted in $90 \%$ acetone for $24 \mathrm{~h}$ at $-20^{\circ} \mathrm{C}$ in the dark (Strickland \& Parsons 1972). 
Stock purity. All liquid stocks used for manipulations including DIP $\left(\mathrm{K}_{2} \mathrm{HPO}_{4}\right), \mathrm{MPn}$ and $\mathrm{NaH}^{13} \mathrm{CO}_{3}$ were tested post-cruise for potential contamination by $\mathrm{Fe}$ and reactive $\mathrm{N}$. Total Fe concentrations in these stocks were determined by isotope dilution $\left({ }^{57} \mathrm{Fe}\right)$ ICP-MS after pre-concentration and matrix removal using NTA (Lohan et al. 2005). Nitrate + nitrite $(\mathrm{N}+\mathrm{N})$ and ammonium $\left(\mathrm{NH}_{4}\right)$ concentrations in all stocks were measured by standard colorimetric methods adapted to an autoanalyzer (Strickland \& Parsons 1972). These analyses indicated that the addition of liquid stocks (DIP $+{ }^{13} \mathrm{C}$ and $\mathrm{MPn}+{ }^{13} \mathrm{C}$ ) to $4.4 \mathrm{l}$ incubation bottles led to $\mathrm{Fe}$ enhancements of $2.7 \mathrm{pmol} \mathrm{l}^{-1}$ and $3.3 \mathrm{pmol} \mathrm{l}^{-1}$ above ambient Fe concentrations, respectively. This level of $\mathrm{Fe}$ contamination is minimal given that total $\mathrm{Fe}$ in the surface waters of the NPSG region are generally between 0.5 and $1.0 \mathrm{nmol}^{-1}$ (Boyle et al. 2005). Total $\mathrm{N}$ contamination $\left(\mathrm{N}+\mathrm{N}+\mathrm{NH}_{4}\right)$ in each 4.41 incubation bottle (DIP $+{ }^{13} \mathrm{C}$ and $\mathrm{MPn}+{ }^{13} \mathrm{C}$ ) was determined to be 0.30 and $0.38 \mathrm{nmol} \mathrm{l}^{-1}$, respectively. For comparison, the mean $\mathrm{N}+\mathrm{N}$ concentrations (not including $\mathrm{NH}_{4}$ ) in the upper $45 \mathrm{~m}$ measured by the Hawaiian Ocean Time-series (HOT) program in July to August of 2008 were 2 to $3 \mathrm{nmol} \mathrm{l}^{-1}$ (data from http://hahana. soest.hawaii.edu/hot/hot-dogs), again suggesting negligible contamination with $\mathrm{N}+\mathrm{N}$ via the addition of stocks. The MPn stock was also tested for the presence of DIP via the MAGIC method of Karl \& Tien (1992); concentrations of DIP were found to be below the detection limit $\left(<1 \mathrm{nmol} \mathrm{l}^{-1}\right)$ of this technique. Thus, despite the relatively high levels of $\mathrm{P}$ additions made in these experiments $\left(5 \mu \mathrm{mol} \mathrm{l}^{-1}\right.$ final concentration above ambient levels), the relative purity of stocks as compared to in situ $\mathrm{Fe}$ and $\mathrm{N}+\mathrm{N}$ concentrations provides confidence that enhanced $\mathrm{C}$ or $\mathrm{N}_{2}$ fixation in experimental treatments derived from the amendment of $\mathrm{P}$.

Statistical analysis. In order to evaluate the probability that derived fixation rates in amended $\mathrm{P}$ treatments are statistically different relative to the controls and each other we computed a one-way ANOVA test followed by an estimation of the Tukey-Kramer Minimum Significant Difference (MSD; Sokal \& Rohlf 1995).

\section{RESULTS}

\section{Phytoplankton standing stock and $\mathbf{P}$ concentrations}

Remote sensing chl a data indicated mesoscale surface enhancements during the July to August 2008 period within each of our cruise regions (Fig. 1). Shipboard determinations during August 2008 indicated in situ mixed layer chl a concentrations (0.07-0.19 $\mathrm{ug} \mathrm{l}^{-1}$ ) were greatest at depths of 25 and $45 \mathrm{~m}$ within a mesoscale patch proximate to the Hawaiian Islands (see Tables 1 and 2). Concentrations of satellite-derived chlorophyll (Fig. 1) did not strictly match measured in situ chl a, presumably stemming from offsets in timing of sampling and the limitation of remote sensing chlorophyll retrievals to the first optical depth (see White et al. 2007 for evaluation of in situ and remotely sensed chl a). Regional MODIS composites show that the OPEREX cruise sampled a mesoscale feature coincident with enhanced chl a while the POOB cruise appears to have sampled a region of regionally enhanced $\mathrm{chl}$ a along the northern edge of the NPSG that continued to bloom after our occupation of the region (Fig. 1B,C). In July 2008, in situ chl a concentrations in the upper mixed layer $(\sim 45 \mathrm{~m})$ near the subtropical front $\left(28-32^{\circ} \mathrm{N}, 140-150^{\circ} \mathrm{W}\right)$ to the northeast of the Hawaiian Islands were generally lower than those measured in August, with concentrations ranging from 0.07 to $0.10 \mu \mathrm{g} \mathrm{l}^{-1}$. During this period, chlorophyll concentrations were greatest $\left(\sim 0.10 \mu \mathrm{g} \mathrm{l}^{-1}\right)$ at stations $7,15,18$, and 19. DIP concentrations within the

Table 1. Chlorophyll a (chl a), dissolved inorganic and organic phosphorus (DIP and DOP, respectively) and nifH gene concentrations measured at stations where coincident $\mathrm{N}_{2}$ or $\mathrm{C}$ fixation rates were available. The range and mean \pm standard deviations are presented. NA: data are not available, as a sample was not collected. ND: gene abundances below the limit of detection $\left(\sim 30\right.$ gene copies $\left.\mathrm{l}^{-1}\right)$. Mean values of DIP, DOP and chl $a$ in the upper $45 \mathrm{~m}$ at Stn ALOHA $\left(22^{\circ} 45^{\prime} \mathrm{N}, 158^{\circ} 00^{\prime} \mathrm{W}\right)$ were obtained from the Hawaii Ocean Time-series (HOT) program. nifH gene concentrations for HOT reflect the range and mean values in the upper $5 \mathrm{~m}$ for unicellular (UCYN-A + Crocosphaera spp.) and filamentous (Het groups + Trichodesmium spp.) diazotrophs

\begin{tabular}{|c|c|c|c|c|c|c|c|}
\hline Cruise & Stns & $\begin{array}{l}\text { Depth } \\
\text { range }(\mathrm{m})\end{array}$ & $\begin{array}{c}\text { DIP } \\
\left(\mathrm{nmol} \mathrm{l}^{-1}\right)\end{array}$ & $\begin{array}{c}\text { DOP } \\
\left(\mathrm{nmol} \mathrm{l}^{-1)}\right.\end{array}$ & $\begin{array}{c}\operatorname{chl} a \\
\left(\mu \mathrm{g} \mathrm{l}^{-1}\right)\end{array}$ & $\begin{array}{l}\text { Unicellular } \mathrm{N}_{2} \text { fixers } \\
\left(\text { nifH genes } \mathrm{l}^{-1} \text { ) }\right.\end{array}$ & $\begin{array}{c}\text { Filamentous } \mathrm{N}_{2} \text { fixers } \\
\quad\left(\text { nifH genes } \mathrm{l}^{-1}\right)\end{array}$ \\
\hline POOB & 1 to 21 & 5 to 45 & $\begin{array}{l}16.0 \text { to } 61.1 \\
29.7 \pm 11.5\end{array}$ & $\begin{array}{c}181 \text { to } 339 \\
246 \pm 38\end{array}$ & $\begin{array}{c}0.07 \text { to } 0.10 \\
0.08 \pm 0.01\end{array}$ & $\begin{array}{c}\text { ND to } 3.1 \times 10^{4} \\
5.8 \times 10^{3} \pm 8.3 \times 10^{3}\end{array}$ & $\begin{array}{c}\text { ND to } 9.0 \times 10^{2} \\
3.1 \times 10^{2} \pm 3.0 \times 10^{2}\end{array}$ \\
\hline OPEREX & $1,3,32$ to 45 & 5 to 45 & $\begin{array}{c}22.2 \text { to } 47.1 \\
37.7 \pm 8.8\end{array}$ & $\begin{array}{c}220 \text { to } 289 \\
251 \pm 30\end{array}$ & $\begin{array}{c}0.07 \text { to } 0.19 \\
0.11 \pm 0.05\end{array}$ & $\begin{array}{l}\text { NA } \\
\text { NA }\end{array}$ & $\begin{array}{l}\text { NA } \\
\text { NA }\end{array}$ \\
\hline НОТ & ALOHA & 0 to 45 & $\begin{array}{l}3.9 \text { to } 163.4 \\
51.5 \pm 30.4\end{array}$ & $\begin{array}{c}107 \text { to } 323 \\
224 \pm 36\end{array}$ & $\begin{array}{l}0.04 \text { to } 0.30 \\
0.09 \pm 0.03\end{array}$ & $\begin{array}{c}5.6 \text { to } 1.8 \times 10^{6} \\
2.1 \times 10^{5} \pm 3.3 \times 10^{5}\end{array}$ & $\begin{array}{c}\text { ND to } 7.4 \times 10^{5} \\
8.7 \times 10^{4} \pm 1.7 \times 10^{5}\end{array}$ \\
\hline
\end{tabular}


mixed layer of this region ranged from 16 to $61 \mathrm{nmol}$ $\mathrm{l}^{-1}$, with a mean $\pm \mathrm{SD}$ of $30 \pm 11 \mathrm{nmol} \mathrm{l}^{-1}$. In contrast, DOP concentrations were significantly greater (181$339 \mathrm{nmol} \mathrm{l}^{-1}$, averaging $246 \pm 38 \mathrm{nmol} \mathrm{l}^{-1}$ ). No significant differences were found between ambient mixedlayer DIP concentrations observed during the OPEREX and POOB cruises ( $t$-test, $\mathrm{p}>0.05, \mathrm{n}=34$ ) despite these studies occurring in disparate regions of the NPSG (Fig. 1). Table 1 presents the composite in situ chl $a$ and $\mathrm{P}$ data for both cruises.

\section{Diazotrophic community structure}

For these 2 cruises, diazotrophic community structure was assessed via QPCR amplification of nifH genes (POOB) or inferred from direct visual observations and size-fractionated $\mathrm{N}_{2}$ rate measurements (OPEREX, discussed in subsequent sections). For the July 2008 expedition (POOB), the spatial distributions of 6 nifH phylotypes were determined. In the well-lit regions of the euphotic zone ( $60 \%$ surface irradiance, 9-20 m) of this region, nifH gene abundances varied approximately an order of magnitude between stations $\left(1.1 \times 10^{2}\right.$ to $1.6 \times 10^{3}$ genes $\left.1^{-1}\right)$, with roughly equal contributions from unicellular and filamentous nifHcontaining cyanobacterial phylotypes (Fig. 3). Among the unicellular $\mathrm{N}_{2}$ fixing cyanobacteria the UCYN-A phylotype dominated the nifH gene abundances (ranging from $2.4 \times 10^{2}$ to $1.6 \times 10^{3}$ nifH genes $\mathrm{l}^{-1}$ ), while the

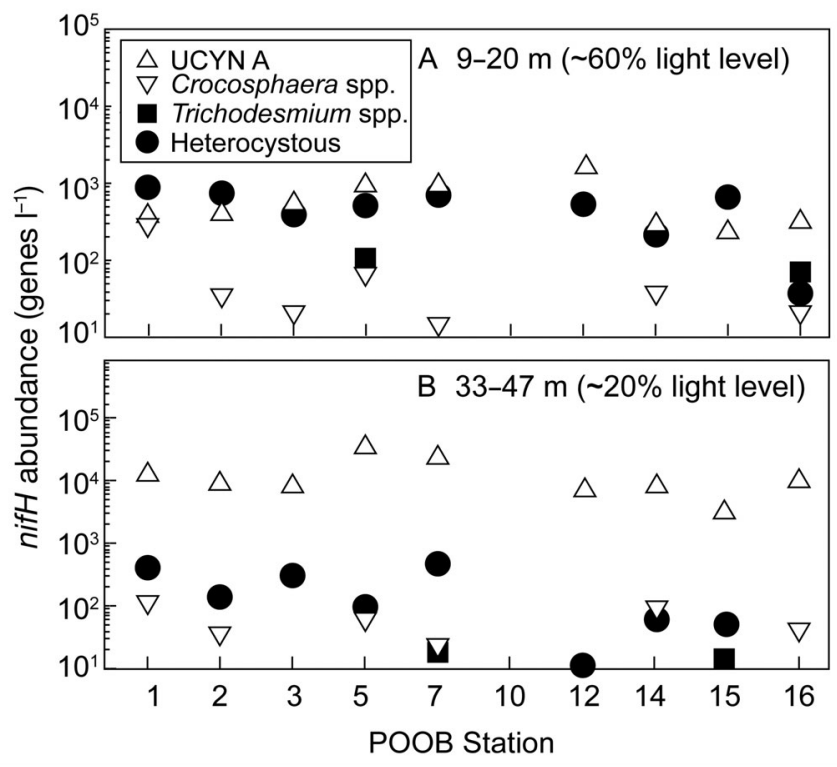

Fig. 3. nifH gene abundances for selected diazotrophs for 2 vertical regions of the euphotic zone measured during the POOB cruise transect: (A) in the upper 9-20 m depth (60\% surface irradiance) and (B) at the $20 \%$ surface irradiance isopleths (33-47 m). Heterocystous includes sum of Het1, Het2, and Het3 cyanobacteria phylotypes (see text for details)
Het2 phylotype (identified as a symbiont of open ocean diatoms belonging to the genera Hemiaulus spp.) was generally the most abundant filamentous cyanobacterial phylotype (ranging from $4.0 \times 10^{2}$ to $7.5 \times 10^{2}$ of the nifH genes $\mathrm{l}^{-1}$ ). nifH gene abundances of the UCYN-A increased more than an order of magnitude (ranging from $2.6 \times 10^{3}$ to $7.6 \times 10^{4}$ nifH genes $\mathrm{l}^{-1}$ ) in the deeper mid-euphotic zone waters $(33-65 \mathrm{~m}$ ) where irradiance declined to $\sim 5-10 \%$ of the surface flux. In contrast, gene abundances of the filamentous cyanobacterial phylotypes decreased below the well-lit, near-surface waters. Relative to the balanced contributions of unicellular and filamentous cyanobacterial phylotypes observed in the well-lit upper ocean, the increase in UCYN-A and concomitant decrease in filamentous phylotypes (specifically Het2) resulted in the numerical dominance of unicellular $\mathrm{N}_{2}$ fixers in the mid to deep euphotic zone waters.

\section{$\mathrm{C}$ and $\mathrm{N}_{2}$ fixation rate: Controls}

Significant variability in the magnitudes of $\mathrm{C}$ and $\mathrm{N}_{2}$ fixation rates of the unamended controls were observed within and between cruises in our study region (Table 2, Fig. 4A). The highest rates of $\mathrm{N}_{2}$ and $\mathrm{C}$ fixation (8-21 nmol N l-1 $\mathrm{d}^{-1}$ and 602-934 nmol C $\mathrm{l}^{-1} \mathrm{~d}^{-1}$, respectively) were recorded in the upper $25 \mathrm{~m}$ of waters with a single high rate of $C$ fixation $(1213 \mathrm{nmol}$ $\mathrm{C}^{-1} \mathrm{~d}^{-1}$ ) at $45 \mathrm{~m}$ at $\mathrm{Stn} 32$ near the Hawaiian Islands in a transition zone between a cyclonic and anticyclonic eddy (Fig. 2B, Table 2). At select stations along this transition zone (Stns 41-45) size-fractionated rate determinations (Fig. 5) indicated that $\mathrm{N}_{2}$ fixation in the

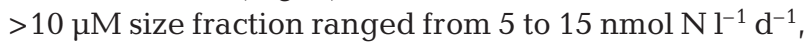
with lower rates measured in the $<10 \mu \mathrm{M}$ size fraction (2-6 nmol $\mathrm{N} \mathrm{l}^{-1} \mathrm{~d}^{-1}$ ). The resulting rates of $\mathrm{N}_{2}$ fixation in $>10 \mu \mathrm{m}$ size fraction accounted for $\sim 63-80 \%$ of the total $\mathrm{N}_{2}$ fixation at these stations. This finding is consistent with the observation of visible Trichodesmium biomass in this region. Total $\mathrm{C}$ fixation rates were also

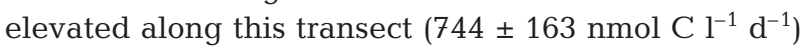
with the $<10 \mu \mathrm{m}$ size fraction accounting for $657 \pm$

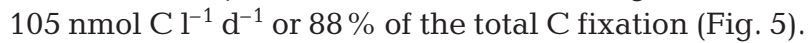

In contrast to the relatively high rates of $\mathrm{N}_{2}$ fixation observed in the waters near Hawaii, rates of $\mathrm{N}_{2}$ and $\mathrm{C}$ fixation were substantially lower $\left(0.02-2.37 \mathrm{nmol} \mathrm{N}^{-1}\right.$

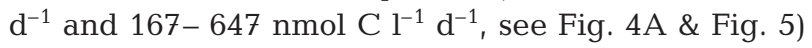
along the edge of the subtropical front (POOB). Rates of $\mathrm{N}_{2}$ fixation in this region were greatest near the edge of an anticyclonic eddy (Stns 7, 10; Fig. 2A, Table 2). Fig. 5A shows the full range of $\mathrm{N}_{2}$ fixation rates measured in the upper $45 \mathrm{~m}$ for both cruises relative to range of ${ }^{15} \mathrm{~N}_{2}$ fixation data available in the literature for the NPSG region. 
Table 2. Magnitude of $\mathrm{N}_{2}$ and $\mathrm{C}$ fixation rates in control incubations (no added $\mathrm{P}$ ) and the enhanced rates measured after methylphosphonate (MPn) and dissolved inorganic phosphorus (DIP) additions (less the values recorded in parallel controls). Values in parentheses: SD of duplicate measures for controls and the SD calculated via error propagation for differences. NA: data were not collected at this station

\begin{tabular}{|c|c|c|c|c|c|c|c|c|c|}
\hline \multirow[t]{2}{*}{ Cruise } & \multirow[t]{2}{*}{ Stn } & \multirow[t]{2}{*}{ Depth } & \multicolumn{3}{|c|}{${ }^{15} \mathrm{~N}_{2}$ fixation $\left[\mathrm{nmol} \mathrm{N} \mathrm{^{-1 }} \mathrm{d}^{-1}\right]$} & \multicolumn{3}{|c|}{${ }^{13} \mathrm{C}$ fixation $\left[\mathrm{nmol} \mathrm{C} \mathrm{l}^{-1} \mathrm{~d}^{-1}\right]$} & \multirow{2}{*}{$\begin{array}{l}\operatorname{chl} a \\
\mu \mathrm{g} \mathrm{l}^{-1}\end{array}$} \\
\hline & & & Control & MPn-Control & DIP-Control & Control & MPn-Control & DIP-Control & \\
\hline \multirow{27}{*}{ POOB } & 1 & 5 & 0.02 & 0.24 & 0.20 & 302 & $0(7)$ & $41(40)$ & 0.06 \\
\hline & 1 & 25 & 0.08 & 0.62 & 0.27 & 364 & 41(148) & $33(18)$ & 0.07 \\
\hline & 2 & 5 & 0.89 & 2.87 & 2.53 & 570 & 414 & 431 & 0.07 \\
\hline & 2 & 25 & $1.16(0.45)$ & $3.36(0.90)$ & $2.53(0.46)$ & $366(52)$ & $702(184)$ & 804(159) & 0.07 \\
\hline & 2 & 45 & $1.04(0.40)$ & $2.00(1.39)$ & $3.10(1.11)$ & 265(15) & $671(122)$ & $438(423)$ & 0.08 \\
\hline & 3 & 5 & 1.10 & 4.11 & 3.18 & 433 & 166 & 203 & 0.08 \\
\hline & 3 & 44 & $1.49(0.02)$ & $2.36(0.20)$ & $1.85(0.20)$ & $333(14)$ & $306(243)$ & $265(114)$ & 0.09 \\
\hline & 5 & 45 & $0.92(0.06)$ & $6.90(0.28)$ & $6.63(1.79)$ & $295(2)$ & $149(104)$ & $91(15)$ & 0.08 \\
\hline & 7 & 5 & 2.32 & 4.75 & 4.71 & 599 & 48 & 107 & 0.09 \\
\hline & 7 & 42 & $1.02(0.02)$ & $3.43(0.05)$ & $4.81(0.60)$ & $415(32)$ & $130(124)$ & 201(33) & 0.09 \\
\hline & 10 & 25 & 2.37 & 3.17 & 4.96 & 428 & 225 & 187 & 0.07 \\
\hline & 10 & 45 & $0.98(0.03)$ & $2.90(0.18)$ & $3.48(0.52)$ & $339(8)$ & $42(25)$ & $5(45)$ & 0.08 \\
\hline & 12 & 45 & $0.04(0.01)$ & $2.88(0.21)$ & $2.91(0.28)$ & $271(34)$ & $122(35)$ & $121(59)$ & 0.07 \\
\hline & 14 & 25 & 0.76 & 2.94 & 2.15 & 377 & 128 & 118 & 0.07 \\
\hline & 14 & 45 & $0.59(0.03)$ & $3.31(0.32)$ & $1.51(2.45)$ & $244(56)$ & $377(131)$ & $217(60)$ & 0.07 \\
\hline & 15 & 45 & $0.24(0.03)$ & $2.29(1.50)$ & $1.77(0.59)$ & $286(7)$ & $310(83)$ & $177(120)$ & 0.10 \\
\hline & 16 & 45 & $0.07(0.1)$ & $3.30(0.02)$ & $3.49(0.52)$ & $287(42)$ & $203(48)$ & $251(47)$ & 0.07 \\
\hline & 17 & 20 & NA & NA & 4.08 & $189(0.2)$ & NA & 297 & 0.08 \\
\hline & 17 & 40 & $0.04(0.05)$ & NA & $2.72(0.36)$ & $226(11)$ & NA & 164 & 0.08 \\
\hline & 18 & 20 & $0.04(0.06)$ & NA & $5.49(0.16)$ & $167(94)$ & NA & 380 & 0.09 \\
\hline & 18 & 40 & $0.02(0.02)$ & NA & $2.94(0.04)$ & $291(6)$ & NA & 119 & 0.07 \\
\hline & 19 & 20 & NA & NA & 6.72 & 549(19) & NA & 88 & 0.09 \\
\hline & 19 & 40 & $0.09(0.13)$ & NA & $5.31(0.45)$ & $353(61)$ & NA & 87 & 0.08 \\
\hline & 20 & 20 & $0.09(0.03)$ & NA & $8.58(0.63)$ & $647(24)$ & NA & 68 & 0.07 \\
\hline & 20 & 40 & $0.21(0.18)$ & NA & $6.83(0.23)$ & $330(5)$ & NA & 360 & 0.07 \\
\hline & 21 & 20 & 0.97 & NA & 10.8 & 388(1) & NA & 354 & 0.08 \\
\hline & 21 & 40 & $0.85(0.06)$ & NA & $7.90(0.49)$ & $336(9)$ & NA & 419 & 0.08 \\
\hline \multirow[t]{16}{*}{ OPEREX } & 1 & 25 & 1.83 & $4.86(1.18)$ & $6.11(1.4)$ & 461 & $229(37)$ & $133(37)$ & 0.08 \\
\hline & 3 & 5 & 2.06 & $8.48(5.51)$ & $7.82(0.86)$ & 500 & 119(43) & $105(32)$ & 0.07 \\
\hline & 3 & 25 & 1.89 & $4.52(0.84)$ & $5.73(5.46)$ & 377 & $269(128)$ & $102(128)$ & 0.07 \\
\hline & 32 & 25 & 1.74 & 21.23 & $16.61(4.88)$ & 445 & 579 & 988(269) & 0.16 \\
\hline & 32 & 45 & 2.84 & $22.55(7.64)$ & 25.43 & 1213 & $-377(469)$ & 365 & 0.19 \\
\hline & 36 & 45 & 0.1 & 1.13 & $1.11(0.21)$ & $249(6)$ & 390 & $322(125)$ & 0.08 \\
\hline & 41 & 25 & 12.67 & NA & NA & 782 & NA & NA & 0.10 \\
\hline & 41 & 45 & 2.48 & NA & NA & 529 & NA & NA & 0.14 \\
\hline & 42 & 25 & 17.66 & NA & NA & 641 & NA & NA & NA \\
\hline & 42 & 45 & 4.31 & NA & NA & 734 & NA & NA & NA \\
\hline & 43 & 25 & 20.52 & NA & NA & 602 & NA & NA & NA \\
\hline & 43 & 45 & 5.19 & NA & NA & 653 & NA & NA & NA \\
\hline & 44 & 25 & 19.82 & NA & NA & 934 & NA & NA & 0.12 \\
\hline & 44 & 45 & 5.49 & NA & NA & 650 & NA & NA & 0.11 \\
\hline & 45 & 25 & 7.62 & NA & NA & 672 & NA & NA & 0.11 \\
\hline & 45 & 45 & 2.70 & NA & NA & 465 & NA & NA & NA \\
\hline
\end{tabular}

\section{$\mathrm{C}$ and $\mathrm{N}_{2}$ fixation rate: Treatments}

Enhancement of $\mathrm{C}$ and $\mathrm{N}_{2}$ fixation rates in experimental treatments was calculated by subtracting the rate measured in the manipulation (+DIP or +MPn) from that measured in the control (no $\mathrm{P}$ addition) (data are shown in Table 2, Fig. 4B,C \& Fig. 5A,B). In both cruises DIP and MPn amended samples displayed enhanced $\mathrm{C}$ and $\mathrm{N}_{2}$ fixation relative to controls in nearly every paired incubation, however at times large SDs were associated with duplicates (Table 2). This enhancement was not correlated to nifH gene abundances, chl $a$, or concentrations of particulate carbon or nitrogen as an indicator of biomass during POOB (regression analyses not shown). However, $\mathrm{N}_{2}$ fixation in $\mathrm{P}$ enhanced treatments during OPEREX displayed a strong correlation with $\mathrm{chl}$ a concentration (least squares linear regression, $\mathrm{r}^{2}=0.88$ and 0.89 for $+\mathrm{MPn}$ and +DIP enhanced $\mathrm{N}_{2}$ fixation rates, respectively).

In order to evaluate the difference between pooled treatments for each cruise, we utilized ANOVA and a post hoc Tukey-Kramer assessment of pairwise differ- 


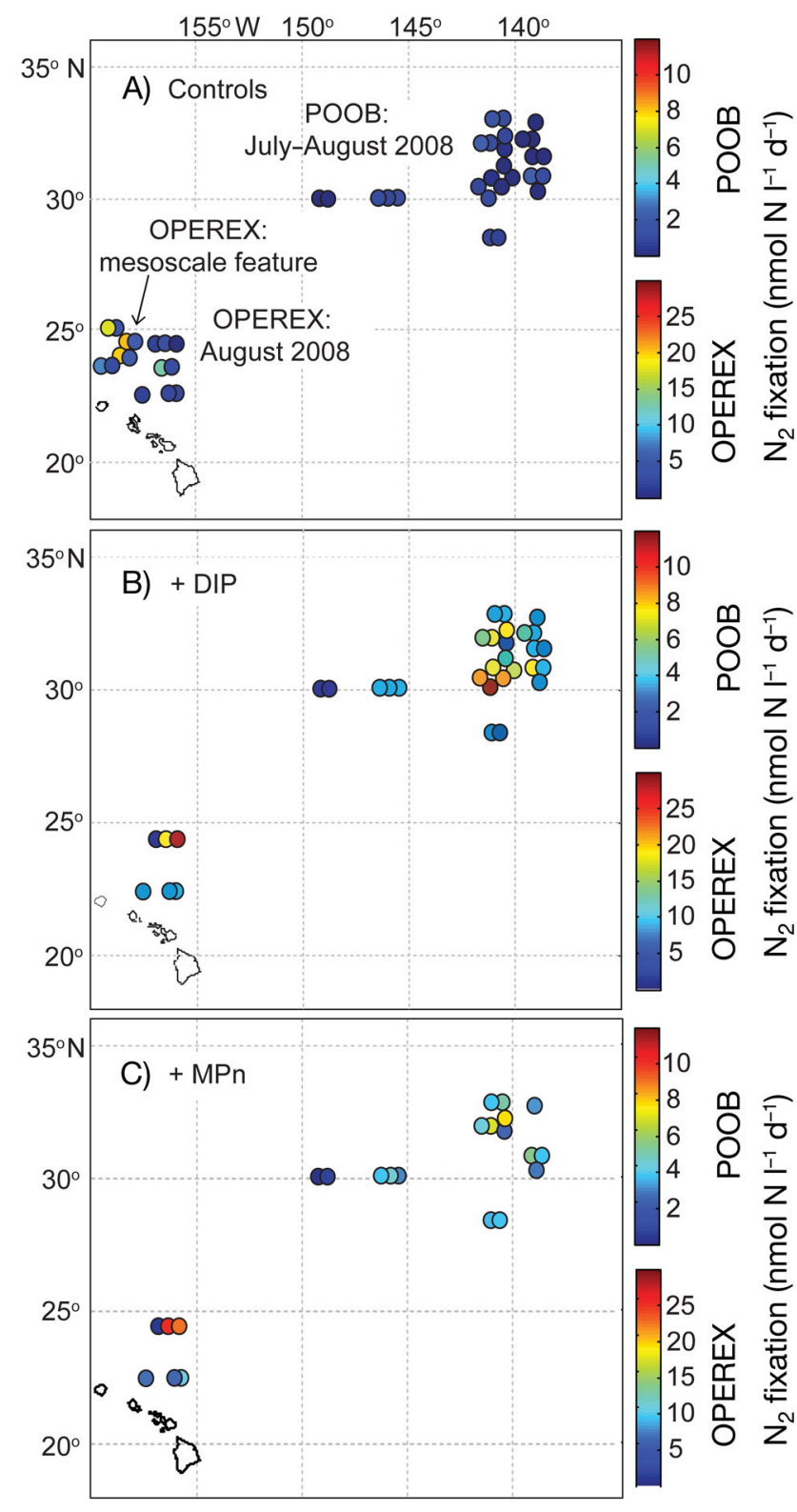

Fig. 4. (A) Bulk seawater $\mathrm{N}_{2}$ fixation (no exogenous additions) measured during OPEREX and POOB. Note different scales for each cruise as OPEREX rates were notably higher than $\mathrm{POOB}$ and the $\mathrm{P}$ additions were markedly higher than controls. (B) $\mathrm{N}_{2}$ fixation rates in response to DIP additions and (C) MPn additions for these same cruises. The color of each dot represents the magnitude of $\mathrm{N}_{2}$ fixation corresponding to the appropriate color bar. Values from duplicate incubations are shown

ences in $\mathrm{C}$ and $\mathrm{N}_{2}$ fixation rates (using absolute volumetric rates as well as chlorophyll normalized rates, Table 3). Results indicate that treatments (+DIP and $+\mathrm{MPn})$ were significantly different from controls for both cruises when considering both volumetric and chlorophyll normalized rates (Table 3 ). The only
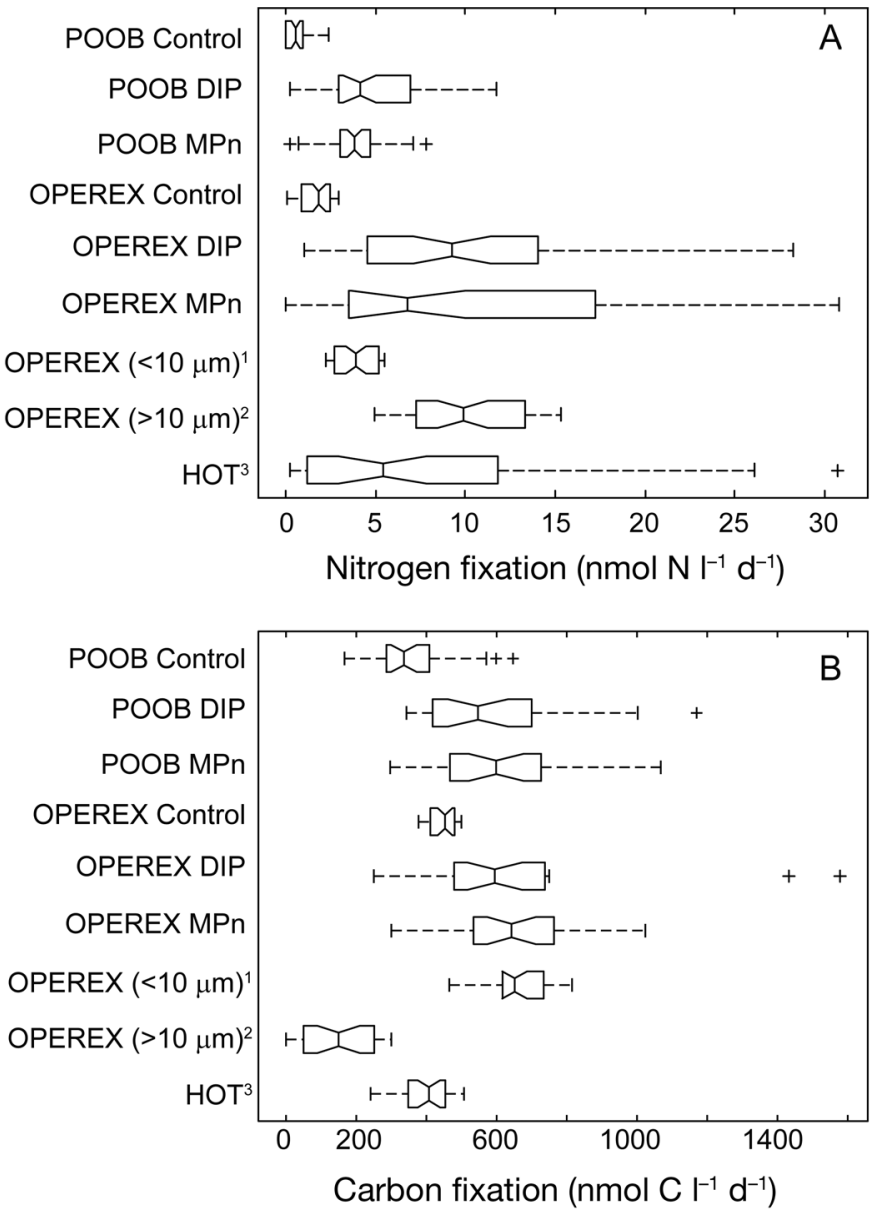

Fig. 5. (A) Summary of $N_{2}$ fixation and (B) carbon fixation rates from both POOB and OPEREX control and manipulation experiments (control rates not deducted) along with (superscripts 1 and 2) size-fractionated rate measurements $(<10 \mu \mathrm{m}$ and $>10 \mu \mathrm{m}$ fractions, respectively), data from a zone of convergence between 2 eddies (Stns 41-45) during OPEREX and (superscript 3) historical data from the HOT time series data presented in Grabowski et al. (2008), Fong et al. (2008) and Church et al. (2009). Box edges represent the 25 and $75 \%$ percentiles of the data, the median is shown as a solid line within each box, the notches represent $95 \%$ confidence intervals, whiskers extend to \pm 2.7 standard deviations of each data set and outliers are denoted by plus signs

exception to this finding is the comparison of OPEREX DIP amendments to controls for $\mathrm{N}$ fixation, where low rates of $\mathrm{N}_{2}$ fixation found at Stn 36 (Table 2) lead to an insignificant difference between DIP amendments and the unamended controls for this cruise (Table 3). When considering grouped comparison of treatments and enhancements for each paired incubation, it is apparent that $\mathrm{P}$ amendments led to widespread enhancement of $\mathrm{C}$ and $\mathrm{N}_{2}$ fixation in this region. Comparing the highest $\mathrm{N}_{2}$ fixation rates measured along this transect, we also find that, despite the high levels of $\mathrm{P}$ added, enhanced $\mathrm{N}_{2}$ fixation rates were within \pm 2.75 standard 
Table 3. Significance of difference in microbial activity between treatments and controls for carbon and nitrogen fixation rates based on the Tukey-Kramer honestly significant difference test. Values presented are the absolute mean difference less the least squares difference. Positive values show pairs of means that are significantly different at the $95 \%$ significance level; these are noted with an asterisk

\begin{tabular}{|c|c|c|c|c|c|c|}
\hline & \multirow{2}{*}{ Control } & \multirow{2}{*}{$\begin{array}{l}\text { POOB } \\
\text { DIP }\end{array}$} & \multirow[b]{2}{*}{ MPn } & \multicolumn{2}{|c|}{$\longrightarrow$ OPEREX } & \multirow[b]{2}{*}{ MPn } \\
\hline & & & & Control & DIP & \\
\hline \multicolumn{7}{|c|}{ Volumetric analysis } \\
\hline \multicolumn{7}{|c|}{${ }^{13} \mathrm{C}$ fixation } \\
\hline Control & - & $133.4^{*}$ & $136.6^{*}$ & - & -26.0 & $64.9^{*}$ \\
\hline DIP & $133.4^{*}$ & - & -86.8 & -26.0 & - & -244.0 \\
\hline MPn & $136.6^{*}$ & -86.8 & - & $64.9^{*}$ & -244.0 & - \\
\hline \multicolumn{7}{|c|}{${ }^{15} \mathbf{N}_{2}$ fixation } \\
\hline Control & - & $3.19^{*}$ & $2.00^{*}$ & - & -0.25 & $0.23^{*}$ \\
\hline DIP & $3.19^{*}$ & - & -0.09 & -0.25 & - & -7.90 \\
\hline MPn & $2.00^{*}$ & -0.09 & - & $0.23^{*}$ & -7.90 & - \\
\hline \multicolumn{7}{|c|}{$\begin{array}{l}\text { Chlorophyll normalized } \\
{ }^{13} \mathbf{C} \text { fixation }\end{array}$} \\
\hline Control & - & $1670^{*}$ & $1746^{*}$ & - & $1651^{*}$ & $2555^{*}$ \\
\hline DIP & $1670^{*}$ & - & -1182 & $1651^{*}$ & - & -1352 \\
\hline MPn & $1746^{*}$ & -1182 & - & $2555^{*}$ & -1352 & - \\
\hline \multicolumn{7}{|c|}{${ }^{15} \mathbf{N}_{2}$ fixation } \\
\hline Control & - & $40.8^{*}$ & $25.9^{*}$ & - & $26.8^{*}$ & $25.6^{*}$ \\
\hline DIP & $40.8^{*}$ & - & -1.4 & $26.8^{*}$ & - & -50.3 \\
\hline MPn & $25.9^{*}$ & -1.4 & - & $25.6^{*}$ & -50.3 & - \\
\hline
\end{tabular}

the magnitude and variability of $\mathrm{C}$ fixation in response to MPn and DIP additions drove the ratio of $\mathrm{C}: \mathrm{N}$ fixation (Fig. 6). The lowest C:N enhancement ratios observed within this cruise region were at Stns 5-12 and 19-21 and corresponded to the most significant enhancements of $\mathrm{N}_{2}$ fixation (Fig. 5). At these stations, the ratio of enhanced $\mathrm{C}: \mathrm{N}$ fixation ranged from 2 to $70 \mathrm{~mol} \mathrm{C}: \mathrm{mol} \mathrm{N}$ with a mean $\pm \mathrm{SD}$ of $30 \pm 19$ mol C:mol $\mathrm{N}$ for pooled DIP and MPn treatments. For the remainder of the POOB dataset, where $\mathrm{N}_{2}$ fixation rates were relatively low, the ratio of enhanced $\mathrm{C}: \mathrm{N}$ fixation exceeded 50 mol C:mol N (Fig. 6).

A large range of $\mathrm{C}: \mathrm{N}$ fixation ratios is well established for laboratory cultures of diazotrophs and for natural populations that can be isolated from the remainder of the microbial assemblage, e.g. Trichodesmium. Rate determinations in natural populations of Trichodesmium colonies collected from various locations and in culture experiments with isolated Trichodesmium

deviations of historical rate measurements for the NPSG measured at Station ALOHA (Fig. 5A).

Beyond analysis of the difference between treatments and controls, we also evaluated the difference between the microbial response to MPn relative to DIP. No significant differences were found in either the rate of $\mathrm{C}$ or $\mathrm{N}_{2}$ fixation stimulated by these exogenous $\mathrm{P}$ additions within either cruise (Table 3). These data suggest that within a single photoperiod, MPn and DIP contributed equally to the observed stimulation of $\mathrm{N}_{2}$ and $\mathrm{C}$ fixation.

The measured ratio of $\mathrm{C}$ fixation to $\mathrm{N}_{2}$ fixation was also calculated in order to assess the relative contribution of diazotrophs to total $\mathrm{C}$ production. Molar C:N fixation ratios (Fig. 6) were calculated as the absolute difference of $\mathrm{C}$ fixation rates (treatment less control) divided by the absolute difference of $\mathrm{N}_{2}$ fixation rates (treatment less control). In the paired MPn and DIP treatments ( $\mathrm{n}=6$ pairs) conducted during the OPEREX cruise, the ratio of $\mathrm{C}: \mathrm{N}$ fixation ranged from undetectable to $47 \mathrm{~mol} \mathrm{C:mol} \mathrm{N}$ for MPn treatments and 13 to $59 \mathrm{~mol} \mathrm{C:mol} \mathrm{N}$ for DIP treatments. One station (the $45 \mathrm{~m}$ sample at Stn 36) exhibited order of magnitude increases in enhanced C:N fixation ratios (345 and 291 mol C:mol $\mathrm{N}$ for MPn and DIP treatments, respectively) driven by low rates of $\mathrm{N}_{2}$ fixation at this depth relative to enhanced $\mathrm{C}$ fixation (Fig. 6). Within the POOB dataset for the frontal region of the NPSG, strains result in $\mathrm{C}: \mathrm{N}$ fixation ratios ranging from 2 to 133 (Mulholland \& Capone 2000, Mulholland \& Bernhardt 2005, Mulholland et al. 2006). Using this information, we can assume that observations of enhanced $\mathrm{C}: \mathrm{N}$ fixation ratios well above the upper edge of the known range for isolates (133) which coincide with relatively low $\mathrm{N}_{2}$ fixation rates represents a minimal contribution from diazotrophs (i.e. high $\mathrm{C}: \mathrm{N}$ fixation driven by enhanced $C$ fixation relative to $N$ ). In other words, we have conservatively assumed that if $\mathrm{C}: \mathrm{N}$ fixation ratios exceed 133 then non-diazotrophic $C$ fixation must have been stimulated by $\mathrm{P}$ additions. By this proxy, there were several stations encountered during POOB $(2-3,14-15)$ where enhanced $C$ fixation rates cannot be fully explained by diazotrophy as C:N fixation ratios exceeded 133 (Fig. 6). Conversely, diazotrophs may have been responsible for a significant complement of $\mathrm{C}$ and $\mathrm{N}$ fixation during OPEREX at all stations other than Stn 36.

\section{DISCUSSION}

Variability in volumetric $\mathrm{N}$ fixation rates in nature is fundamentally driven by changes in either cell specific growth rates, diazotrophic biomass, or both. The diverse assemblage of microbes having the capacity to fix $\mathrm{N}_{2}$ in the upper ocean exhibit a wide range of cell- 


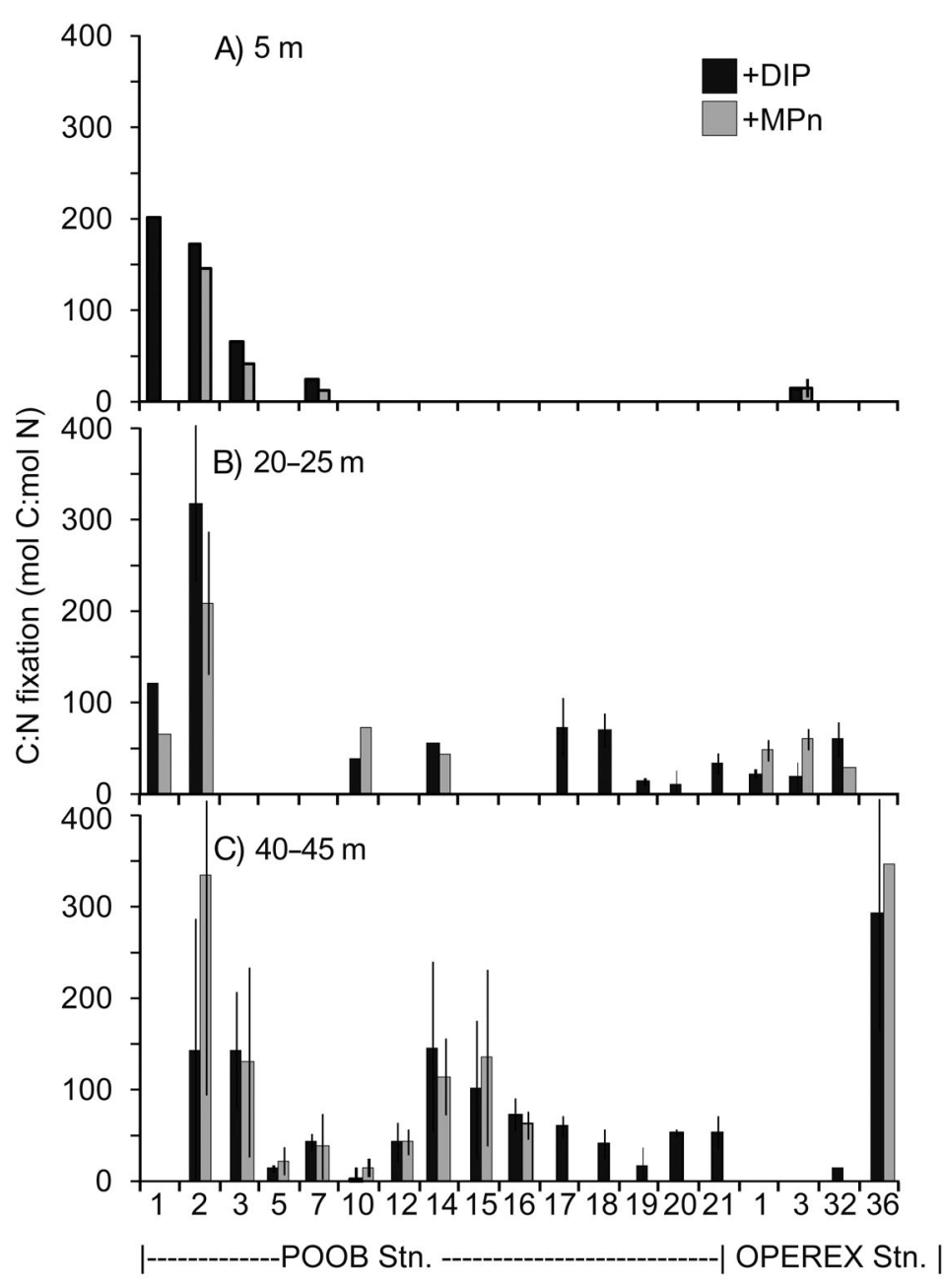

Fig. 6. Mean molar C:N fixation ratios of the enhanced production calculated as DIP and MPn rates less controls for the (A) upper $5 \mathrm{~m}$, (B) 20-25 $\mathrm{m}$ and (C) 40-45 $\mathrm{m}$ depth horizons. Station and depth with no data correspond to instances when samples were not collected at a specific depth range. Error bars represent standard deviations

specific rates of $\mathrm{N}_{2}$ fixation (Goebel et al. 2008) so that the absolute rate of $\mathrm{N}_{2}$-fixation measured at any one time and location is partially a reflection of community structure and the combined physiological state of the diazotrophic assemblage. In the open ocean, 3 major classes of diazotrophs have been identified to date: (1) species of the non-heterocystous, filamentous cyanobacterium Trichodesmium, (2) heterocystous cyanobacteria including those known to exist as symbionts with select genera of oceanic diatom species, and (3) groups of small unicellular diazotrophs (Zehr \& Ward 2002, Church et al. 2008). At the time of this study our observations suggest that surface waters $(<20 \mathrm{~m})$ of the northern edge of the NPSG (SST $\sim 22^{\circ} \mathrm{C}$ ) were codominated by UCYN-A and heterocystous Richelia with UCYN-A becoming more abundant in the mid- euphotic zone (33-65 m, Fig. 3). Visual observations of surface slicks and size-fractionated rate measurements indicate that transects along the more central NPSG region near the Hawaiian islands $\left(\mathrm{SST} \sim 26^{\circ} \mathrm{C}\right.$ ) sampled in August 2008 were conversely dominated by large colony-forming Trichodesmium spp. The salient differences in the size and physiology of each of these diazotrophic phylotypes suggests that they may differentially affect primary productivity, $\mathrm{N}_{2}$ fixation, elemental cycles and the fate of organic matter in the surface ocean. While we do not have any reliable means to assess total number of $\mathrm{N}_{2}$ fixing cells and thus normalize rate measurements to diazotrophic biomass, our results indicate that at the time of our sampling the warmer central NPSG supported a higher mean rate of $\mathrm{N}_{2}$ and $\mathrm{C}$ fixation than the cooler boundary waters to the north (Figs. 4 \& 5). Moreover, enhanced $\mathrm{C}$ and $\mathrm{N}_{2}$ fixation was observed in association with mesoscale features (Fig. 2), a finding that is consistent with previous studies and likely reflects either physical aggregation of diazotrophic cells or injections (advection or upwelling) of limiting nutrients to the surface mixed layer (Davis \& McGillicuddy 2006, Fong et al. 2008, Church et al. 2009). The significant enhancement of $\mathrm{N}$ fixation rates observed in the $\mathrm{P}$ amended treatments, the strong correlation between enhanced rates and chl a concentrations and the large $(>60 \%)$ contribution of the $>10 \mu \mathrm{m}$ size fraction of the microbial assemblage to bulk $\mathrm{N}_{2}$ fixation all seem to confirm the relevance of Trichodesmium as a major component of the diazotrophic assemblage in these mesoscale features at the time of this study.

Beyond observation of the variability of diazotrophic diversity in the NPSG, a central objective of this research was to determine if the variability of ambient $\mathrm{N}_{2}$ and $\mathrm{C}$ fixation in this region was a consequence of differential $\mathrm{P}$ resource limitation. To examine whether $\mathrm{P}$ concentrations limited the metabolic activity of natural populations of diazotrophs, we conducted a series of $\mathrm{P}$ amendment experiments over a spatially extensive area of the NPSG. In contrast to previous experiments in oligotrophic surface waters, which focused on DIP (and/or Fe) additions (e.g. Mills et al. 2004, Rees et al. 2006, Grabowski et al. 2008), we also sought to investigate the response of $\mathrm{N}_{2}$ and $\mathrm{C}$ fixation rates to the addition of a presumably bioavailable DOP compound, MPn, relative to the response to DIP additions. MPn was selected as a test compound since it is known to be readily utilized by the diazotroph Tri- 
chodesmium (Karl et al. 2008, White et al. 2010) and phosphonate hydrolysis pathways are considered to provide a competitive advantage in low $\mathrm{P}$ environments (Dyhrman et al. 2007, Quinn et al. 2007) such as the NPSG. Relatively high doses of P $\left(5 \mu \mathrm{mol} \mathrm{l}^{-1}\right)$ were added to ensure that saturating but not inhibitory levels of nutrient enrichment were achieved. The single most salient finding of these experiments was that both MPn and DIP stimulated statistically similar $\mathrm{C}$ and $\mathrm{N}_{2}$ fixation rates over a single photoperiod (Table 3 ). This result suggests that both compounds can support primary productivity and diazotrophy with similar efficiency when added in excess. Equivalent enhancements of productivity via MPn or DIP additions may at first seem at odds with the prevailing perception of DIP as more bioavailable than DOP (Cembella et al. 1982). However, DOP uptake is contingent upon the presence of enzymes capable of cleaving the C-P linkage in MPn enzymes which have been documented in this region (Karl et al. 2008). Moreover, laboratory experiments have shown that for at least the diazotroph Trichodesmium, $\mathrm{C}$ and $\mathrm{N}$ based growth rates are statistically similar when $\mathrm{P}$ is supplied as $\mathrm{P}$ monoesters, phosphonates or DIP (White et al. 2010). White et al. (2010) have hypothesized that this finding is a reflection of energy-replete growth. In sum, we would suggest that enhanced growth in response to either MPn or DIP is consistent with an energy replete, P stressed diazotrophic assemblage poised to rapidly cleave $\mathrm{P}$ from organic moieties, and hence the availability of both DIP and DOP may regulate primary production and $\mathrm{N}_{2}$ fixation on daily time-scales in this ecosystem.

Several other investigators have examined the role of $\mathrm{P}$ as a regulator of $\mathrm{N}_{2}$ fixation in the subtropical gyres. Grabowski et al. (2008) conducted a series of manipulation experiments (+DIP, $+\mathrm{Fe},+\mathrm{DIP}$ and $\mathrm{Fe}$ ) in May 2004 to March 2005 at Station ALOHA in the NPSG, the time-series station of the HOT program. In their study, the addition of 160 to $320 \mathrm{nmol}^{-1} \mathrm{P}$ and/or $20 \mathrm{nmol} \mathrm{l}^{-1}$ Fe followed by a $24 \mathrm{~h}$ incubation period resulted in significant variability in the relative response of $\mathrm{N}_{2}$ fixation rates to nutrient amendments, ranging from insignificant changes in $\mathrm{N}_{2}$ fixation to a near doubling of rates in response to Fe, to DIP, and to dual amendments. Heterogeneity of the microbial response to nutrient amendments was also observed in the North Atlantic where Mills et al. (2004) observed a doubling of $\mathrm{N}_{2}$ fixation rates at one site in response to both $\mathrm{P}$ and $\mathrm{Fe}$ additions, while 2 other sites sampled did not differ from unamended controls. In contrast, in our experiments we observed consistently enhanced $\mathrm{N}_{2}$ fixation in response to large $\mathrm{P}$ dosages (DIP and MPn) at nearly all stations along a broad expanse of the NPSG (Table 1). The uniformity of this result may be related to a dose-response relationship, i.e. $\mathrm{P}$ addi- tion levels were sufficient to result in maximal uptake rates. Combining our results with previous studies provides additional support for the hypothesis that $\mathrm{P}$ availability can restrict rates of $\mathrm{N}_{2}$ fixation in the NPSG.

The finding that the availability of $\mathrm{P}$ can regulate $\mathrm{N}_{2}$ fixation does not necessarily imply that the full microbial community is $\mathrm{P}$ limited. In fact, $\mathrm{P}$ restriction of new $\mathrm{N}$ inputs via $\mathrm{N}_{2}$ fixation may contribute to proximate $\mathrm{N}$ limitation of the remaining microbial consortia. Addition experiments such as those conducted in this research provide a snapshot of the bulk nutritional status of resident microbial populations. Results based on short-term experiments must be interpreted in the context of the variability in microbial physiology and resource-based competition. As such, the nutritional status of a diverse community would be regulated by small and often undetectable fluctuations in nutrient input and consumption rates as well as the competitive interactions of the microorganisms (Tilman 1982). Different constituents of the microbial assemblage are probably limited by different inorganic or organic nutrients at any given point in time. The enhancement of metabolic activity in a fraction of the microbial assemblage due to the sudden excess availability of a single particular nutrient can have a cascading effect, providing other needed resources to the remaining microbial assemblage (Van Mooy \& Devol 2008, Bonnet et al. 2010). Although a cascading effect may be difficult to detect over a $24 \mathrm{~h}$ incubation, previous experiments in these waters suggest that $C$ fixation by picophotoautotrophs is rapidly enhanced when incubated in the presence of Trichodesmium filaments (Letelier \& Karl 1998).

This cascading effect can help explain why MPn and DIP additions led to stimulation of $\mathrm{C}$ fixation rates in excess of those that could be attributed to diazotrophic activity (C:N fixation ratios $>>100$ ) at 1 station during OPEREX and at several stations during POOB (Table 1, Fig. 6). The apparent uncoupling of $C$ and $N_{2}$ fixation at these locations may reflect bulk community $\mathrm{P}$ limitation or diazotroph-mediated production of bioavailable nitrogen (DIN or DON) which stimulated plankton community growth or both. Additionally, a recent study suggests that the conventional ${ }^{15} \mathrm{~N}_{2}$ tracer method used herein may underestimate $\mathrm{N}_{2}$ fixation rates (Mohr et al. 2010). If this is the case for our study, then our findings would suggest that $\mathrm{P}$ restricted growth of only diazotrophs rather than exerting a community-wide limitation of other photoautotrophs. We have used a relatively high ratio of C:N fixation (133) as an upper bound for ratios characteristic of diazotrophs and since this ratio was derived using the same methodology as employed in our own study $\left({ }^{15} \mathrm{~N}_{2}\right.$ and ${ }^{13} \mathrm{C}$ tracer approaches), we believe that $\mathrm{N}_{2}$ fixation alone cannot uniformly account for the full comple- 
ment of enhanced $\mathrm{C}$ fixation across our study region. $\mathrm{P}$ appears to have stimulated some portion of the nondiazotrophic microbial consortia in a subset of our sampling region, particularly within POOB stations (Fig. 6) and may thus imply a more taxonomically extensive $\mathrm{P}$ limitation along the edges of the NPSG where diazotroph abundances were dominated by unicellular cyanobacteria. In order to fully unravel the underlying mechanisms for uncoupling of $\mathrm{C}$ and $\mathrm{N}_{2}$ fixation a rigorous examination of the fate of fixed $\mathrm{N}_{2}$ in natural populations is necessary.

Despite our observations of $\mathrm{P}$ restricted $\mathrm{N}_{2}$ fixation, our results alone cannot define the temporal persistence of $\mathrm{P}$ limitation in this region. To examine the scale of diazotrophic P limitation in the NPSG, we have compared our results to the historical record of diazotrophy available via the Hawaii Ocean Time-series. The majority of $\mathrm{N}_{2}$ fixation rates achieved by either MPn or DIP additions fell within the range of rates measured in the NPSG (Fig. 5, median enhancements for each cruise are within $95 \%$ confidence intervals for HOT data). These results indicate that $\mathrm{P}$ limitation may be a transitory occurrence in this region; i.e. $\mathrm{P}$ may be only one of several factors regulating $\mathrm{N}_{2}$ fixation in the NPSG over seasonal and interannual time scales. Other resources such as Fe as well as food web dynamics (e.g. predation, lysis) and physical aggregation of diazotrophic biomass by mesoscale forcing also likely constrain diazotroph biomass and rates of $\mathrm{N}_{2}$ fixation in this region. It is also entirely likely that there is no single limiting factor driving the large variability observed for both $\mathrm{N}_{2}$ fixation rates and the abundance of $\mathrm{N}_{2}$ fixing organisms in this region (Dore et al. 2008, Church et al. 2009). In this context, studies detailing the similarities and differences in the controls of biomass and productivity of the major classes of diazotrophs are still missing. In summary, results of these $\mathrm{P}$ amendment experiments demonstrated that the productivity of diazotrophic communities was restricted by bioavailable P over a broad geographical expanse of the NPSG under typical summer conditions. While we do not yet have a mechanistic model for constraining the observed variability of oceanic $\mathrm{N}_{2}$ fixation, the data presented here indicate that the physical and biological processes that regulate $\mathrm{P}$ availability play an important role in the regulation of $\mathrm{C}$ and $\mathrm{N}$ fluxes in the NPSG.

Acknowledgements. Support for this project was provided by the National Science Foundation (OCE-0623596 and OCE0850827). We thank chief scientist M. Brzezinski of the Pacific Open Ocean Bloom cruise; chief scientist Z. Kolber of the Ocean PERturbation EXperiment cruise; the captain and crew of the Kilo Moana and numerous colleagues from the University of Hawai'i, particularly B. Updyke for his assistance with sample collection; the Center for Microbial Oceanography:
Research and Education (C-MORE) and Oregon State University Ocean Microbial Ecology Laboratory (OMEL). We also thank Z. Chase, J. Jennings and M. Kavanaugh for trace element analyses, nutrient analyses, and input regarding statistical methods, respectively.

\section{LITERATURE CITED}

Björkman KM, Karl DM (2003) Bioavailability of dissolved organic phosphorus in the euphotic zone at Station ALOHA, North Pacific Subtropical Gyre. Limnol Oceanogr 48:1049-1057

Björkman KM, Thomson-Bulldis AL, Karl DM (2000) Phosphorus dynamics in the North Pacific subtropical gyre. Aquat Microb Ecol 22:185-198

Bonnet S, Webb E, Panzeca C, Karl D, Capone D, SañudoWilhelmy S (2010) Vitamin B12 excretion by cultures of the marine cyanobacteria Crocosphaera and Synechococcus. Limnol Oceanogr 55:1959-1964

Boyle E, Bergquist BA, Kayser RA, Mahowald N (2005) Iron, Manganese, and Lead at Hawaii Ocean Timeseries Station ALOHA: Temporal Variability and an Intermediate Water Hydrothermal Plume. Geochim Cosmochim Acta 69:933-952

Capone DG (2001) Marine nitrogen fixation: What's the fuss? Curr Opin Microbiol 4:341-348

Cembella AD, Antia NJ, Harrison PJ (1982) The utilization of inorganic and organic phosphorous compounds as nutrients by eukaryotic microalgae: a multidisciplinary perspective: I. Crit Rev Microbiol 10:317-391

Church MJ, Jenkins BD, Karl DM, Zehr JP (2005) Vertical distributions of nitrogen-fixing phylotypes at Stn ALOHA in the oligotrophic North Pacific Ocean. Aquat Microb Ecol 38:3-14

Church MJ, Björkman K, Karl D, Saito M, Zehr J (2008) Regional distributions of nitrogen-fixing bacteria in the Pacific Ocean. Limnol Oceanogr 53:63-77

Church MJ, Mahaffey C, Letelier RM, Lukas R, Zehr JP, Karl DM (2009) Physical forcing of nitrogen fixation and diazotroph community structure in the North Pacific subtropical gyre. Global Biogeochem Cycles 23:GB2020, doi: 2010.1029/2008GB003418

Davis CS, McGillicuddy DJ (2006) Transatlantic abundance of the $\mathrm{N}_{2}$-fixing colonial cyanobacterium Trichodesmium. Science 312:1517-1520

> Dominic B, Chen Y, Zehr J (1998) Cloning and transcriptional analysis of the nifUHDK genes of Trichodesmium sp. IMS101 reveals stable nifD, nifDK and nifK transcripts. Microbiology 144:3359

Dore J, Letelier R, Church M, Lukas R, Karl D (2008) Summer phytoplankton blooms in the oligotrophic North Pacific Subtropical Gyre: historical perspective and recent observations. Prog Oceanogr 76:2-38

> Duhamel S, Dyhrman ST, Karl DM (2010) Alkaline phosphatase activity and regulation in the North Pacific Subtropical Gyre. Limnol Oceanogr 55:1414-1425

Dyhrman ST, Chappell PD, Haley ST, Moffett JW, Orchard ED, Waterbury JB, Webb EA (2006) Phosphonate utilization by the globally important marine diazotroph Trichodesmium. Nature 439:68-70

Dyhrman S, Ammerman J, Van Mooy B (2007) Microbes and the marine phosphorus cycle. Oceanography (Wash DC) 20:110-116

Fong AA, Karl DM, Lukas R, Letelier RM, Zehr JP, Church MJ (2008) Nitrogen fixation in an anticyclonic eddy in the oligotrophic North Pacific Ocean. ISME J 2:663-676 
Goebel N, Edwards C, Carter B, Achilles K, Zehr J (2008) Growth and carbon content of three different-sized diazotrophic cyanobacteria observed in the subtropical North Pacific. J Phycol 44:1212-1220

Grabowski M, Church M, Karl D (2008) Nitrogen fixation rates and controls at Stn ALOHA. Aquat Microb Ecol 52: 175-183

Hutchins DA, Fu F, Zhang Y, Warner ME and others (2007) $\mathrm{CO}_{2}$ control of Trichodesmium $\mathrm{N}_{2}$ fixation, photosynthesis, growth rates, and elemental ratios: Implications for past, present, and future ocean biogeochemistry. Limnol Oceanogr 52:1293-1304

Karl DM (2002) Nutrient dynamics in the deep blue sea. Trends Microbiol 10:410-418

Karl DM, Björkman KM (2002) Dynamics of DOP. In: Hansell DA, Carlson CA (eds) Biogeochemistry of marine dissolved organic matter. Academic Press, London, p 249-366

Karl DM, Tien G (1992) MAGIC: a sensitive and precise method for measuring dissolved phosphorus in aquatic environments. Limnol Oceanogr 37:105-116

Karl D, Letelier R, Tupas L, Dore J, Christian J, Hebel D (1997) The role of nitrogen fixation in biogeochemical cycling in the subtropical North Pacific Ocean. Nature 388:533-538

Karl D, Björkman K, Dore J, Fujieki L and others (2001a) Ecological nitrogen-to-phosphorus stoichiometry at station ALOHA. Deep-Sea Res II 48:1529-1566

Karl DM, Bidigare RR, Letelier RM (2001b) Long-term changes in plankton community structure and productivity in the North Pacific Subtropical Gyre: The domain shift hypothesis. Deep-Sea Res II 48:1449-1470

Karl DM, Michaels A, Bergman B, Capone DG and others (2002) Dinitrogen fixation in the world's oceans. Biogeochem 57/58:47-98

Karl DM, Beversdorf L, Björkman KM, Church MJ, Martinez A, Delong EF (2008) Aerobic production of methane in the sea. Nat Geosci 1:473-478

Kolowith LC, Ingall ED, Benner R (2001) Composition and cycling of marine organic phosphorus. Limnol Oceanogr 46:309-320

Legendre L, Gosselin M (1997) Estimation of N or C uptake rates by phytoplankton using ${ }^{15} \mathrm{~N}$ or ${ }^{13} \mathrm{C}$ : revisiting the usual computation formulae. J Plankton Res 19:263

Letelier RM, Karl DM (1998) Trichodesmium spp. physiology and nutrient fluxes in the North Pacific subtropical gyre. Aquat Microb Ecol 15:265-276

Lohan M, Aguilar-Islas A, Franks R, Bruland K (2005) Determination of iron and copper in seawater at $\mathrm{pH} 1.7$ with a new commercially available chelating resin, NTA Superflow. Anal Chim Acta 530:121-129

> Mahaffey C, Michaels AF, Capone DG (2005) The conundrum of marine $\mathrm{N}_{2}$ fixation. Am J Sci 305:546-595

> McCarthy JJ, Carpenter EJ (1979) Oscillatoria (Trichodesmium) thiebautii (Cyanophyta) in the central North Atlantic Ocean. J Phycol 15:75-82

Mills MM, Ridame C, Davey M, La Roche J, Geider RJ (2004) Iron and phosphorus co-limit nitrogen fixation in the eastern tropical North Atlantic. Nature 429:292-294

Mohr W, Großkopf T, Wallace D, LaRoche J, Finkel Z (2010) Methodological Underestimation of Oceanic Nitrogen Fixation Rates. PLoS ONE 5:e12583

Montoya JP, Voss M, Kahler P, Capone DG (1996) A simple high-sensitivity tracer assay for $\mathrm{N}_{2}$ fixation. Appl Environ Microbiol 62:986-993

Moore C, Mills M, Langlois R, Milne A, Achterberg E, La Roche J, Geider R (2008) Relative influence of nitrogen

Editorial responsibility: Ronald Kiene,

Mobile, Alabama, USA and phosphorous availability on phytoplankton physiology and productivity in the oligotrophic sub-tropical North Atlantic Ocean. Limnol Oceanogr 53:291-305

- Mulholland MR, Bernhardt PW (2005) The effect of growth rate, phosphorus concentration, and temperature on $\mathrm{N}_{2}$ fixation, carbon fixation, and nitrogen release in continuous cultures of Trichodesmium IMS101. Limnol Oceanogr 50:839-849

Mulholland MR, Capone DG (2000) The nitrogen physiology of the marine $\mathrm{N}_{2}$-fixing cyanobacteria Trichodesmium spp. Trends Plant Sci 5:148-153

Mulholland M, Bernhardt P, Heil C, Bronk D, O'Neil J (2006) Nitrogen fixation and release of fixed nitrogen by Trichodesmium spp. in the Gulf of Mexico. Limnol Oceanogr 51:1762-1776

> Perry M, Eppley R (1981) Phosphate uptake by phytoplankton in the central North Pacific Ocean. Deep-Sea Res A, Oceanogr Res Pap 28:39-49

Quinn JP, Kulakova AN, Cooley NA, McGrath JW (2007) New ways to break an old bond: the bacterial carbon-phosphorus hydrolases and their role in biogeochemical phosphorus cycling. Environ Microbiol 9:2392-2400

> Rees A, Law C, Woodward E (2006) High rates of nitrogen fixation during an in-situ phosphate release experiment in the Eastern Mediterranean Sea. Geophys Res Lett 33: L10607, doi:10.1029/2006GL025791

Sañudo-Wilhelmy SA, Kustka AB, Gobler CJ, Hutchins DA and others (2001) Phosphorus limitation of nitrogen fixation by Trichodesmium in the central Atlantic Ocean. Nature 411:66-69

Sohm JA, Capone DG (2006) Phosphorus dynamics of the tropical and subtropical north Atlantic: Trichodesmium versus bulk plankton. Mar Ecol Prog Ser 317:21-28

Sokal RR, Rohlf FJ (1995) Biometry: the principles and practice of statistics in biological research. Freeman, New York

Strickland J, Parsons TR (1972) A practical handbook of seawater analysis. Bulletin 167, 2nd edn., Fish Res Board Can, Queen's Printer, Ottawa

Tilman D (1982) Resource competition and community structure, Vol 17. Princeton University Press, Princeton

Valderrama JC (1981) The simultaneous analysis of total nitrogen and total phosphorus in natural waters. Mar Chem 10:109-122

Van Mooy B, Devol A (2008) Assessing nutrient limitation of Prochlorococcus in the North Pacific subtropical gyre by using an RNA capture method. Limnol Oceanogr 53: 78-88

> Vitousek P, Howarth R (1991) Nitrogen limitation on land and in the sea: How can it occur? Biogeochem 13:87-115

White AE, Spitz YH, Letelier RM (2007) What factors are driving summer phytoplankton blooms in the North Pacific Subtropical Gyre. J Geophys Res 112:C12006, doi:10. 4319/10.2010.55.4.1755

> White AE, Karl DM, Björkman KM, Beversdorf L, Letelier RM (2010) Production of organic matter by Trichodesmium IMS101 as a function of phosphorus source. Limnol Oceanogr 55:1755-1767

Wu J, Sunda W, Boyle E, Karl D (2000) Phosphate depletion in the western North Atlantic Ocean. Science 289:759

Zehr JP, Ward BB (2002) Nitrogen Cycling in the Ocean: New Perspectives on Processes and Paradigms. Appl Environ Microbiol 68:1015-1024

> Zehr JP, Waterbury JB, Turner PJ, Montoya JP and others (2001) Unicellular cyanobacteria fix $\mathrm{N}_{2}$ in the subtropical North Pacific Ocean. Nature 412:635-638

Submitted: November 5, 2010; Accepted: March 23, 2011

Proofs received from author(s): June 14, 2011 